THE AMERICAN JOURNAL OF AGRICULTURE AND BIOMEDICAL

\title{
ENGINEERING
}

[Volume-II Issue-VI][Pages = XVI-XXIII] [2020]

Website: www.usajournalshub.com

ISSN (e): 2689-1018

\section{Influence Of Galangin On Respiration And Oxidative Phosphorylation Of Rat Liver Mitochondria}

Yusupova Umida, Department of Human and Animal Physiology, PhD, National University of Uzbekistan named after Mirzo Ulugbek, Tashkent, Uzbekistan*

Mamatova Zulaykho, Head of Department of Human and Animal Physiology, PhD assistant professor, National University of Uzbekistan named after Mirzo Ulugbek, Tashkent, Uzbekistan

Dzhabbarova Gulchehra, Human and Animal Physiology, PhD assistant professor, National University of Uzbekistan named after Mirzo Ulugbek, Tashkent, Uzbekistan

Tukhtaeva Feruza, Physiology of humans and animals, intern, National University of Uzbekistan named after Mirzo Ulugbek, Tashkent, Uzbekistan

Almatov Karim, Department of Human and Animal Physiology, Professor, National University of Uzbekistan named after Mirzo Ulugbek, Tashkent, Uzbekistan

Article Doi - https://doi.org/10.37547/tajabe/Volume02Issue06-02

\begin{abstract}
The influence of galangin on the respiration and oxidative phosphorylation of rat liver mitochondria is studied in vitro conditions. It was found that galangin increases a glutamate oxidation in $V_{2}$ and $V_{4}$ states, but it does not affect on the rate of mitochondrial phosphorylating respiration $\left(V_{3}\right)$. The respiratory quotient value by Chance dose-dependently decreases. High concentration of galangin raises the ADP:O quotient. At the same time, in low concentration the galangin does not influence on the succinate oxidations, however, with increasing of its concentration the mitochondrial respiration by succinate increases simultaneously. Thus the ADP/O quotient decreases significantly and the respiratory quotient value by Chance, on the contrary, decreases slightly.
\end{abstract}

Key words: galangin, respiration, liver mitochondria, phosphorylation, glutamate oxidation, succinate oxidation

* Corresponding author at: Department of Human and Animal Physiology, National University of Uzbekistan, Universitet str. 1, 100174 Tashkent, Uzbekistan. (U.R. Yusupova).

YUSUPOVA UMIDA, MAMATOVA ZULAYKHO, DZHABBAROVA GULCHEHRA, TUKHTAEVA FERUZA \&

ALMATOV KARIM, TAJABE [Volume-I I Issue- VI]

JUN 2020 [www.usajournalshub.com] 


\section{THE AMERICAN JOURNAL OF AGRICULTURE AND BIOMEDICAL ENGINEERING \\ [Volume-II Issue-VI][Pages = XVI-XXIII] [2020] \\ Website: www.usajournalshub.com \\ ISSN (e): 2689-1018}

\section{Introduction}

Among various effects of flavonoids their influence on the structure and functions of mitochondria represents considerable interest (Rustamova et al., 2005; Rustamova et al., 2006; Almatov and Rustamova, 2006; Mamadzhanov et al., 2011). Mitochondrial system of oxidative phosphorylation is one of main factors which determine energetic states of cellular adenine - nucleotides. Primary function of adenine nucleotides consists in interface of all metabolic pathways, therefore state of adenine nucleotide system makes regulative influence on the orientation and rate of metabolic processes, and meantime depends on them. Mitochondria play a key role in cell apoptosis. So, for example, after initiation of an ischemic stress in neurocytes culture the processes connected with the cyclosporinedependent depolarization of a mitochondrial membrane, the decrease of ATP level and the increase of intracellular $\mathrm{Ca}^{2+}$ ions concentration have been registered (White and Reynolds, 1996).

It has been shown (Asai et al., 1999) that a high level of $\mathrm{Ca}^{2+} /$ calmodulin-dependent protein phosphatase (calcineurin) promotes a caspase-dependent apoptosis of neurons. Besides Fas-mediated caspase- 8 and -10 activation at a cerebrum ischemia the caspase- 9 activation which occurs by the mechanism unconnected with "death ligands" has been noted (Cao et al., 2001). In this case mitochondria and Bcl-2 family member proteins participate in an apoptosis initiation. At transitory focal ischemia ( $80 \mathrm{~min}$ ) of cerebrum a fast transition of proapoptic Bax protein of this family from cytoplasm into mitochondria, where it interacts with a voltage-dependent anion channel (VDAC) of the membrane, has been reported (Nutt et al., 2002).

As a result they open and various protoplasmatic mediators leave from mitochondria. Sugawara et al. (2002) have shown that after $5 \mathrm{~min}$ of global ischemia of rat cerebrum the cytochrome $\mathrm{C}$ is released from mitochondria to cytoplasm of CA1 neurons, which together with ATP is necessary for caspase-9 activation and the subsequent cascade of the biochemical reactions leading to neuron apoptosis.

It should be noted that mitochondrial mechanism of apoptosis can be activated also by influence of an another proapoptic protein of Bcl-2-Bid family. As Gross et al. (1999) have shown the caspase- 8 activated by Fas receptor splits an inactive Bid to several fragments. Protein p15 Bid which was formed herewith penetrates from cytoplasm into a membrane of mitochondria, providing a release of cytochrome $\mathrm{C}$ and other proapoptic mediators. Antiapoptic proteins $\mathrm{BCl}-2$ and $\mathrm{Bcl}-\mathrm{XL}$ do not interfere proteolitic splitting of Bid protein and its transport to mitochondria (Plesnila et al., 2001).

Flavonoids have various beneficial biological effects that include antioxidant activity (Horvathova et. Al., 2003). Galangin, 4H-1-benzopyran-4-one, 3,5,7-trihydroxy-2-phenyl or 3,5,7-trihydroxyflavone is a polyphenolic compound obtained mainly from various medicinal herbs. It is believed that it has antimutagenic, antioxidant and inhibitory properties. Most 


\section{THE AMERICAN JOURNAL OF AGRICULTURE AND BIOMEDICAL ENGINEERING \\ [Volume-II Issue-VI][Pages $=$ XVI-XXIII] [2020] \\ Website: www.usajournalshub.com \\ ISSN (e): 2689-1018}

studies of galangin have focused on its anticancer effects. Promising data from epidemiological studies, as well as in vitro studies and animal studies have shown that galangin and the consumption of galangin-containing foods can affect some diseases. (Merve Bacanlı et.al., 2018). Oxidative stress is associated with persistent complications of diabetes, and galangin reduces hyperglycemia. Galangin improved respiratory chain enzyme activity in hyperglycemic rats to the level observed in healthy rats. (Amal A. Aloud et.al., 2017)

This brief review on the studies of molecular interaction mechanisms of flavonoids shows that it is essential to investigate the influence of different representatives of these compounds on one of cell energy supply system - mitochondrial respiration and phosphorylation system. In the present paper some results of the influence of galangin on the respiration and phosphorylation of mitochondria have been presented.

\section{Materials and methods}

Mitochondria were isolated from cells of rat liver according to the method presented in (Schneider and Hogeboom, 1951). The respiration rate mitochondria at a various metabolic states was polarographically registered by rotating platinum electrode. Reactions were started with addition of a mitochondrial suspension into polarographic mesh. The composition of the incubation medium: $0.25 \mathrm{M}$ sucrose, $5 \mathrm{mM} \mathrm{KH}_{2} \mathrm{PO}_{4}, 10 \mathrm{mM}$ Tris-HC1 buffer (pH 7.4). As an oxidizing substrata $10 \mathrm{mM}$ succinate $(\mathrm{pH} 7.4)$ and $10 \mathrm{mM}$ glutamate $(\mathrm{pH}$ 7.4) were used. Respiration and oxidative phosphorylation of mitochondria were analyzed at the consecutive addition of galangin, $200 \mu \mathrm{M} A D P$ and $5.10^{5} \mathrm{M}$ of 2,4Dinitrophenol (DNP). Herewith the following respiration rates of chemicals were determined: $V_{2}$ - state 2 before ADP addition, $V_{3}$ - active phosphorylation state, $V_{4}$ - state 4 after exhaustion of ADP in a mesh. ADP:O ratio and respiratory quotient were calculated by Chance and Williams (1955) $\left(\mathrm{V}_{3}: \mathrm{V}_{4}\right)$ method. The substrate oxidation rate at a various metabolic states was expressed by nanogram oxygen atom/min in $\mathrm{mg}$ of mitochondrial protein. Protein was defined by method of Lowry et al. (1951).

Experiments were carrying out in the absence of flavonoids and with addition of galangin into a polarographic mesh in vitro. Galangin was used in a manner of glycerin solution. The indicated flavonoid solutions were put into polarographic mesh in final concentration of $20,40,60 \mu \mathrm{kg} / \mathrm{mg}$ mitochondrial protein and the features of change of mitocondrial functional state were studied.

3. Results and discussion

The data presented in Table 1 shows that galangin does not influence on the phosphorylative oxidation of glutamate $\left(V_{3}\right)$ in mitochondria, but it accelerates an oxidation rate in metabolic $V_{2}$ and $V_{4}$ states. After addition of 20,40 and $60 \mu \mathrm{kg}$ of apigenin in $1 \mathrm{mg}$ of mitochondrial protein to mitochondrial suspension the glutamate oxidation rate in $\mathrm{V}_{2}$ state raises $32.0,38.0$ and $32.0 \%$ respectively, from control level, and in $V_{4}$ state - 23.1, 37.8 and 


\section{THE AMERICAN JOURNAL OF AGRICULTURE AND BIOMEDICAL ENGINEERING \\ [Volume-II Issue-VI][Pages = XVI-XXIII] [2020] \\ Website: www.usajournalshub.com \\ ISSN (e): 2689-1018}

$36.7 \%$. These changes lead to decreasing the value of respiratory quotient by Chance $\left(V_{3}: V_{4}\right)$ up to $16.5,25.8$ and $29.3 \%$ from control value. Thus it is necessary to notice that galangin in low concentration does not influence on ADP:O quotient, however at higher concentration ( $60 \mu \mathrm{kg} / \mathrm{mg}$ of protein) raises linking parameters of mitochondria up to $8 \%$. If the respiratory quotient value by Chance reflects a communication degree of transformation processes and energy accumulation of mitochondria with energy processes in cell, then the ADP:O value characterizes the functional arrangement of the mechanisms defining the ADP phosphorylation process in the mitochondrial membrane and their communication with activity of a terminal respiratory chain. The large ADP:O value causes the less oxygen spending in phosphorylation, that accordingly higher mitochondrial efficiency from the point of view of an energy storage for the further intracellular metabolic processes.

Table 1

Influence of galangin on glutamate oxidation and oxidative phosphorylation of liver mitochondria ( $M \pm m ; n=8-12)$.

\begin{tabular}{|l|l|l|l|l|}
\hline \multirow{3}{*}{ INDEX } & \multicolumn{4}{l|}{ Respiration rate, nanogram oxygen atom/min in $\mathrm{mg}$ of protein } \\
\cline { 2 - 5 } & \multicolumn{4}{l}{ Galangin, $\mu \mathrm{kg} / \mathrm{mg}$ protein } \\
\cline { 2 - 5 } & 0 & 20 & 40 & 60 \\
\hline $\mathrm{V}_{2}$ & $20.0 \pm 1.4$ & $26.4 \pm 1.4^{* * *}$ & $27.6 \pm 1.5^{* * *}$ & $26.4 \pm 1.4^{* * *}$ \\
\hline$\%$ & 100 & 132.0 & 138.0 & 132.0 \\
\hline $\mathrm{V}_{3}$ & $66.5 \pm 2.0$ & $68.4 \pm 2.3$ & $68.2 \pm 2.5$ & $64.5 \pm 2.3$ \\
\hline$\%$ & 100 & 102.8 & 102.5 & 97.0 \\
\hline $\mathrm{V}_{4}$ & $17.7 \pm 1.5$ & $21.8 \pm 1.6^{* *}$ & $24.4 \pm 1.7^{* * *}$ & $24.2 \pm 1.6^{* * *}$ \\
\hline$\%$ & 100 & 123.1 & 137.8 & 136.7 \\
\hline $\mathrm{V}_{\text {DNP }}$ & $70.4 \pm 2.1$ & $69.2 \pm 2.9$ & $66.6 \pm 3.2$ & $66.0 \pm 3.0$ \\
\hline$\%$ & 100 & 98.3 & 94.6 & 93.7 \\
\hline $\mathrm{RQ}$ & $3.76 \pm 0.14$ & $3.14 \pm 0.12^{* *}$ & $2.79 \pm 0.12^{* * *}$ & $2.66 \pm 0.10^{* * * *}$ \\
\hline$\%$ & 100 & 83.5 & 74.2 & 70.7 \\
\hline ADP:O & $2.73 \pm 0.08$ & $2.77 \pm 0.07$ & $2.87 \pm 0.08$ & $2.95 \pm 0.09$ \\
\hline$\%$ & 100 & 101.4 & 105.1 & 108.0 \\
\hline
\end{tabular}

${ }^{*}$ The quotient authenticity: ${ }^{*} \mathrm{P}<0.05 ;{ }^{* *} \mathrm{P}<0.002 ;{ }^{* * *} \mathrm{P}<0.01 ;{ }^{* * * *} \mathrm{P}<0.001$.

Galangin in low concentration ( $20 \mu \mathrm{kg} / \mathrm{mg}$ protein) does not influence on the oxidation rate of succinate and oxidative phosphorylation in liver mitochondria (Table 2). However, with increasing of galangin concentration a mitochondrial respiration raises in various metabolic succinate states, especially in $\mathrm{V}_{4}$ and $\mathrm{V}_{2}$ states. It is necessary to notice that an increase of succinate oxidation rate depends on carrying in a dose of galangin. So, if

YUSUPOVA UMIDA, MAMATOVA ZULAYKHO, DZHABBAROVA GULCHEHRA, TUKHTAEVA FERUZA \&

ALMATOV KARIM, TAJABE [Volume-I I Issue- VI]

JUN 2020 [www.usajournalshub.com] 


\section{THE AMERICAN JOURNAL OF AGRICULTURE AND BIOMEDICAL ENGINEERING \\ [Volume-II Issue-VI][Pages = XVI-XXIII] [2020] \\ Website: www.usajournalshub.com \\ ISSN (e): 2689-1018}

at presence of galangin $40 \mu \mathrm{kg} / \mathrm{mg}$ of protein, the oxidation rate of succinate in $V_{2}, V_{3}$ and $V_{4}$ states raises up to $29.0,11.2$ and $17.5 \%$ respectively, from the control level, in the presence of $60 \mu \mathrm{kg} / \mathrm{mg}$ of protein it raises up to $52.9,24.8$ and $36.6 \%$. These changes lead to decreasing the value of respiratory quotient by Chance and ADP:O quotient: in the presence of $40 \mu \mathrm{kg} / \mathrm{mg}$ of galangin protein on 5.5 and $13.2 \%, 60 \mu \mathrm{kg} / \mathrm{mg}$ of protein -8.6 and $16.0 \%$.

At presence of dinitrophenol ( $\left.V_{D N P}\right)$ a galangin almost does not influence on oxidation rate of glutamate and succinate. However, higher concentration of galangin $(60 \mu \mathrm{kg} / \mathrm{mg}$ of protein) slightly suppressed dinitrophenolstimulative respiration of mitochondria. It means that higher concentration of galangin inhibits an electron transport from oxidation substrates to molecular oxygen through a mitochondrial respiratory chain.

Table 2

Influence of galangin on succinate oxidation and oxidative phosphorylation of liver mitochondria ( $M \pm m ; n=8-12$ ).

\begin{tabular}{|l|l|l|l|l|}
\hline \multirow{2}{*}{ INDEX } & \multicolumn{4}{l|}{ Respiration rate, nanogram oxygen atom /min in mg of protein } \\
\cline { 2 - 5 } & \multicolumn{4}{ll}{ Galangin, $\mu \mathrm{kg} / \mathrm{mg}$ protein } \\
\cline { 2 - 5 } & 0 & 20 & 40 & 60 \\
\hline $\mathrm{V}_{2}$ & $34.4 \pm 1.8$ & $36.5 \pm 1.9$ & $44.4 \pm 1.9^{* * *}$ & $52.6 \pm 2.4^{* * * *}$ \\
\hline$\%$ & 100 & 106.1 & 129.0 & 152.9 \\
\hline $\mathrm{V}_{3}$ & $124.4 \pm 2.8$ & $125.1 \pm 2.7$ & $138.4 \pm 2.8^{* * *}$ & $155.3 \pm 3.2^{* * * *}$ \\
\hline$\%$ & 100 & 100.5 & 111.2 & 124.8 \\
\hline $\mathrm{V}_{4}$ & $32.5 \pm 1.9$ & $33.8 \pm 1.8$ & $38.2 \pm 1.9^{* *}$ & $44.4 \pm 2.6^{* * *}$ \\
\hline$\%$ & 100 & 104.0 & 117.5 & 136.6 \\
\hline $\mathrm{V}_{\text {DNP }}$ & $162.5 \pm 3.6$ & $158.0 \pm 3.8$ & $166.7 \pm 4.1$ & $148.5 \pm 3.3^{* *}$ \\
\hline$\%$ & 100 & 97.2 & 102.6 & 91.4 \\
\hline RQch $\left(\mathrm{V}_{3}: \mathrm{V}_{4}\right)$ & $3.83 \pm 0.13$ & $3.70 \pm 0.13$ & $3.62 \pm 0.12$ & $3.50 \pm 0.13^{*}$ \\
\hline$\%$ & 100 & 96.6 & 94.5 & 91.4 \\
\hline ADP:O & $1.82 \pm 0.09$ & $1.70 \pm 0.10$ & $1.58 \pm 0.09^{*}$ & $1.53 \pm 0.10^{*}$ \\
\hline$\%$ & 100 & 93.4 & 86.8 & 84.0 \\
\hline
\end{tabular}

${ }^{*}$ The quotient authenticity: ${ }^{*} \mathrm{P}<0.05 ;{ }^{* *} \mathrm{P}<0.002 ;{ }^{* * *} \mathrm{P}<0.01 ;{ }^{* * * *} \mathrm{P}<0.001$.

Thus, analyzing the received results it is possible to conclude that galangin raises a glutamate oxidation in $V_{2}$ and $V_{4}$ states, but does not influence on the phosphorylative respirations of mitochondria. The respiratory quotient value by Chance dose-dependently decreases. High concentration of galangin raises the ADP:O quotient. It means that galangin enhances an ATP synthesis on the basic pathway of a mitochondrial respiratory chain. 


\section{THE AMERICAN JOURNAL OF AGRICULTURE AND BIOMEDICAL ENGINEERING \\ [Volume-II Issue-VI][Pages = XVI-XXIII] [2020] \\ Website: www.usajournalshub.com \\ ISSN (e): 2689-1018}

It is known that in isolated mitochondria the adenine nucleotides inhibit the opening of a pore invoked by $\mathrm{Ca}^{2+}$ and inorganic phosphate, or by $\mathrm{Ca}^{2+}$ and oxidative stress (Crompton, 1999). It was shown that in the experiments including preliminary opening of pore, ADP possesses stronger inhibitor effect. On the other hand, at use of adenine nucleotides for prevention of pore induction, only ATP has been effective.

The difference in influence of adenine nucleotides on induction process is not connected to affinity of ADP and ATP to adenine-nucleotide translocase. It allows to assume that on the basis of adenine-nucleotide effects are based on the different mechanisms of their influence on pore components. Perhaps an ATP influence on pore opening is connected with an interaction with kinases in an outer membrane of mitochondria whereas inhibiting effect of ADP after pore opening can be carried out at the expense of its direct linkage with adenine-nucleotide translocase in inner membrane of mitochondria (Crompton, 1999).

Low concentration of galangin does not influence on the succinate oxidations in mitochondria. However, with increase of galangin concentration the mitochondrial respiration increases and depends on entering doses of galangin. Thus the ADP:O quotient is noticeably, and respiratory control value by Chance slightly decreases.

Acknowledgments

The authors thank professors Khushbaktova Z.A. and Syrov V.N. from the Institute of Chemistry of Plant Substances (Tashkent, Uzbekistan) for kindly providing the galangin.

\section{References}

1. Almatov, K.T., Rustamova, R.P., 2006. Influence of apigenn on phospholipids' content of liver mitochondria. Acta NUUz 1, 64-66.

2. Amal A. Aloud, Chinnadurai Veeramani, Chandramohan Govindasamy, Mohammed A. Alsaif \&Khalid S. Al-Numair. (Galangin, a natural flavonoid reduces mitochondrial oxidative damage in streptozotocin-induced diabetic rats.Pages 29-34 | Published online: 16 Aug 2017

3. Asai, A., Qiu, J., Narita, Y., Chi, S., Saito, N., Shinoura, N., Hamada, H., Kuchino, Y., Kirino T., 1999. High level calcineurin activity predisposes neuronal cells to apoptosis. J. Biol. Chem. 274, 3450-3458.

4. Cao, G., Minami, M., Pei, W., Yan, C., Chen, D., O'Horo, C., Graham, S.H., Chen, J., 2001. Intracellular Bax translocation after transient cerebral ischemia: implications for a role of the mitochondrial apoptosis signaling pathway in ischemic neuronal death. J. Cereb. Blood. Flow Metab. 21, 321-333.

5. Chance, B., Williams, G.R., 1955. Respiratory enzymes in oxidative phosporylation. IV. The respiratory chain. J. Biol. Chem. 217, 429-438.

6. Crompton, M., 1999. The mitochondrial permeability transition pore and its role in cell death. Biochem. J. 341, 233-249. 


\section{THE AMERICAN JOURNAL OF AGRICULTURE AND BIOMEDICAL ENGINEERING \\ [Volume-II Issue-VI][Pages = XVI-XXIII] [2020] \\ Website: www.usajournalshub.com \\ ISSN (e): 2689-1018}

7. Gross, A., Yin, X.M., Wang, K., Michael, C., Wei, M.C., Jockel, J., Milliman, C., Erdjument-Bromage, H., Tempst, P., Korsmeyer, S.J., 1999. Caspase cleaved BID targets mitochondria and is required for cytochrome $\mathrm{c}$ release, while $\mathrm{Bcl}-\mathrm{XI}$ prevents this release but not tumor necrosis factor-R1/Fas death. J. Biol. Chem. 274, 1156-1163.

8. Horvathova K, Novotny L, Vachalkova A. The free radical scavenging activity of four flavonoids determined by the comet assay. Neoplasma. 2003;50(4):291-295. [PubMed], [Web of Science ${ }^{\circledR}$ ], [Google Scholar].

9. Lowry, O.H., Rosebrough, N.J., Farr, A.L., Randall, R.J., 1951. Protein measurement with the Folin phenol reagent. J. Biol. Chem. 193, 265-274.

10. Mamadzhanov, M.M., Khushbaktova, Z.A., Klemesheva, L.S., Almatov K.T., 2011. Influence of vexybinal and glabranin on respiratory and energetic functions of mitochondria. Acta NUUz 2, 103-105.

11. Merve BacanlıA. Ahmet BaşaranNurşen Başaran (Galangin as a Plant Phenolic and Usage in Health and Disease., in Polyphenols: Prevention and Treatment of Human Disease (Second Edition), 2018.

12. Nutt, L.K., Chandra, J., Pataer, A., Fang, B., Roth, J.A., Swisher, S.G., O'Neil, R.G., McConkey, D.J., 2002. Bax-mediated $\mathrm{Ca}^{2+}$ mobilization promotes cytochrome c release during apoptosis. J. Biol. Chem. 277, 20301-20308.

13. Plesnila, N., Zinkel, S., Le, D.A., Amin-Hanjani, S., Wu, Y., Qiu, J., Chiarugi, A., Thomas, S.S., Kohane, D.S., Korsmeyer, S.J., Moskowitz, M.A., 2001. BID mediates neuronal cell death after oxygen/glucose deprivation and focal cerebral ischemia. Proc. Natl. Acad. Sci. USA 98, 15318-15323.

14. Rustamova, R.P., Irgasheva, G.M., Khushbaktova, Z.A., Shirinova, I.A., Klemesheva, L.S., Almatov, K.T., 2005 Influence of some flavons on energetic metabolism of mitochondria. Report \#1. Voprosi biologicheskoi, medicinskoi i farmacevticheskoi chimii 4, 39-48.

15. Rustamova, R.P., Irgasheva, G.M., Khushbaktova, Z.A., Shirinova, I.A., Klemesheva, L.S., Almatov, K.T., 2006. Influence of flavons on energetic metabolism of mitochondria. Report \#2. Voprosi biologicheskoi, medicinskoi i farmacevticheskoi chimii 2, 16-20.

16. Schneider, W.C., Hogeboom, G.N., 1951. Cytochemical studies of mammalian tissues; the isolation of cell components by differential centrifugation: a review. Cancer. Res. $11,1-22$.

17. Sugawara, T., Noshita, N., Lewén, A., Gasche, Y., Ferrand-Drake, M., Fujimura, M., Morita-Fujimura, Y., Chan, P.H., 2002. Overexpression of copper/zinc superoxide dismutase in transgenic rats protects vulnerable neurons against ischemic damage by blocking the mitochondrial pathway of caspase activation. J. Neurosci. 22, 209-217. 
THE AMERICAN JOURNAL OF AGRICULTURE AND BIOMEDICAL ENGINEERING

[Volume-II Issue-VI][Pages = XVI-XXIII] [2020]

Website: www.usajournalshub.com ISSN (e): 2689-1018

18. White, R.J., Reynolds, I.J., 1996. Mitochondrial depolarization in glutamatestimulated neurons: An early signal specific to excitotoxin exposure. J. Neurosci. 16, 56885697. 